\title{
DEVELOPMENT AND VALIDATION OF UV SPECTROSCOPIC METHOD OF PALIPERIDONE PALMITATE IN BULK AND ITS APPLICATION FOR DRUG LOADING AND ENTRAPMENT EFFICIENCY ANALYSIS OF LONG-ACTING INJECTABLE MICROSPHERES
}

\author{
NISHANT OZA, SANDIP MALI ${ }^{*}$ \\ Department of Pharmaceutical Science, Research, Development and Innovation Centre (RDIC), C. U. Shah University, Wadhwan City, \\ Surendranagar 363030, Gujarat, India \\ *Email: sandiplmali@rediffmail.com
}

Received: 23 Mar 2021, Revised and Accepted: 29 Apr 2021

\section{ABSTRACT}

Objective: The objective of the current study was to develop simple, precise and cost-effective ultraviolet (UV) spectroscopic method for estimation of paliperidone palmitate (PP) as a bulk and in the polymeric depot dosage form.

Methods: UV spectrophotometer with quartz sample cells and spectral manager software was used for analysis samples. $20 \%$ Methanol in Mili-QWater was used as a solvent for the sample and standard preparations. Method validation was carried out as per ICH Q2 (R1) guidelines. Stress degradation studies were carried out to check the stability-indicating performance of the developed method. The validated method was applied for the estimation of the PP content of long-acting injectable microspheres of PP.

Results: The wavelength of maximum absorption was found to be $283 \mathrm{~nm}$. The proposed method was validated in the range of 5-30 $\mu \mathrm{g} / \mathrm{ml}$ of PP The mean recovery for $80 \%, 100 \%$ and $120 \%$ standard solution was found to be $99.03 \%, 99.21 \%$ and $99.35 \%$ respectively with less than $2 \%$ relative standard deviation (RSD). Intra-day and inter-day method precision ranged from 0.54 to $1.62 \%$ and 0.67 and $1.24 \%$ respectively. Limit of detection (LOD) and limit of quantitation (LOQ) were estimated to be 0.03 and $0.10 \mu \mathrm{g} / \mathrm{ml}$ respectively. The developed method was found to be robust and rugged. Stress degradation studies were carried out under acidic, alkaline, hydrolytic and oxidative and photo stress. The proposed method was capable to detect changes in assay due to stress conditions.

Conclusion: The developed method was successfully employed for routine analysis of drug loading in long-acting injectable microspheres of PP.

Keywords: UV spectroscopy, Method validation, Paliperidone palmitate, Stress degradation, Drug loading, Microspheres

(C) 2021 The Authors. Published by Innovare Academic Sciences Pvt Ltd. This is an open access article under the CC BY license (https://creativecommons.org/licenses/by/4.0/)

DOI: https://dx.doi.org/10.22159/ijap.2021v13i4.41583. Journal homepage: https://innovareacademics.in/journals/index.php/ijap

\section{INTRODUCTION}

Paliperidone palmitate (PP) is newer widely prescribed atypical antipsychotics for the treatment of schizophrenia [1-3]. PP belongs to the class of benzisoxazole derivatives. The chemical name is (9RS)-3-[2-[4-(6-Fluoro1,2-benzisoxazol-3-yl)piperidin-1-yl]ethyl]2-methyl-4-oxo-6,7,8,9-tetrahydro-4Hpyrido [1,2-a] pyrimadin-9-yl hexadecanoate. Paliperidone palmitate is a prodrug and it gets hydrolyzed to paliperidone. It was postulated that the drug's therapeutic effect in schizophrenia may be due to a combination of central dopamine type 2 (D2) and serotonin Type 2 (5HT2A) receptor antagonism. PP is very slightly soluble in ethanol and methanol, practically insoluble in polyethylene glycol 400 and propylene glycol, and slightly soluble in ethyl acetate [4].

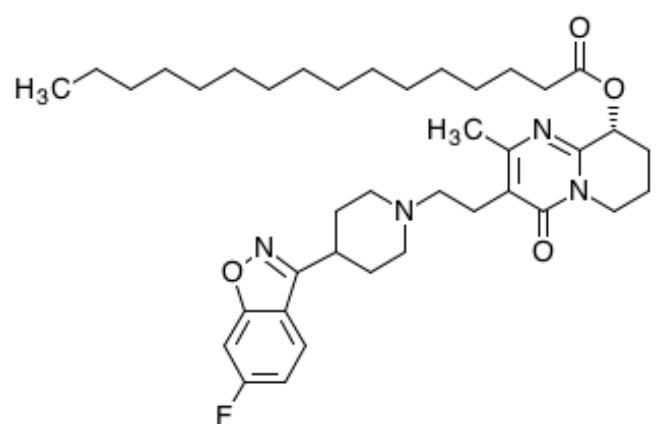

Fig. 1: Chemical structure of paliperidone palmitate

In the treatment of schizophrenia, the recommended dose of PP tablets in adults is $6 \mathrm{mg}$ administered once daily and is recommended for long-term administration. PP was considered to be an ideal drug candidate to formulate in extended-release drug formulation via the parenteral route of administration. Poly(lacticco-glycolic acid) (PLGA) is a well-known biodegradable and biocompatible polymer used to formulate drug in long acting injectable dosage form. PLGA based microsphere formulations of various drugs were successfully developed for the injectable application. Polymeric microspheres are capable to deliver the encapsulated drug for long term via parenteral administration [5-7].

Historically, UV spectroscopic methods were proved very beneficial for quantification purposes in pharmaceutical analytical research [811]. The literature search of available UV spectroscopy methods [1214] showed that three UV methods were reported for estimation of $\mathrm{PP}$ in pharmaceutical drug products. Several high-performance liquid chromatography (HPLC) methods [15-18] have been reported for the determination of paliperidone-free base in bulk and tablet dosage forms. Very limited scientific investigations were found that demonstrate the development and validation of analytical methods for PP and in long-acting injectable microsphere formulation.

Based on the detailed review of methods for estimation PP, a new UV spectrophotometric method was developed for the determination of PP in bulk as well as to estimate drug loading and entrapment efficiency of long-acting injectable microspheres. In this research work, significant efforts were made to develop a newer, simple, easy, precise, sensitive, accurate and cost-effective UV spectroscopy method for analysis of PP in bulk and microspheres dosage form.

\section{MATERIALS AND METHODS}

Instruments and reagents

A double beam UV-visible spectrometer (UV-1700, Shimadzu, Japan) with the spectra manager software was used for the analysis with quartz cells having $10 \mathrm{~mm}$ path length for spectral measurement. 
Weighing balance (Mettler Toledo, USA) with internal calibration mode was used for the accurate weighing purpose. PP was obtained as a gift sample from Glenmark life sciences, India. Methanol, sodium hydroxide, hydrochloric acid and hydrogen peroxide were purchased from Merck, Germany. All the chemicals of analytical grade were used in the proposed study.

\section{Preparation of stock solution}

Accurately weighed $10 \mathrm{mg}$ of PP was transferred to a $100 \mathrm{ml}$ volumetric flask, dissolved in $20 \mathrm{ml}$ methanol by shaking manually for $10 \mathrm{~min}$. The volume of solution was adjusted with the Mili-QWater up to the $100 \mathrm{ml}$ mark to give the final strength i.e. $100 \mu \mathrm{g} / \mathrm{ml}$.

\section{Selection of wavelength of maximum absorbance}

Appropriate volume $(3 \mathrm{ml})$ of the standard stock solution was transferred into a $10 \mathrm{ml}$ volumetric flask, diluted to a mark with distilled water to give a concentration of $30 \mu \mathrm{g} / \mathrm{ml}$. The resulting solution was scanned in the UV range (200 to $400 \mathrm{~nm}$ ). The UV spectrum of PP was shown in fig. 2. In UV spectrum, PP showed maximum absorbance at a wavelength of $283 \mathrm{~nm}$.

\section{Preparation of calibration curve}

Different aliquots of stock solution in the range of 0.5 to $3 \mathrm{ml}$ were transferred into a series of $10 \mathrm{ml}$ volumetric flasks, and the volume was made up to the mark with Mili-Q-water to get concentrations 5 , $10,15,20,25$ and $30 \mu \mathrm{g} / \mathrm{ml}$, respectively. The solutions were scanned on a UV spectrophotometer in the range of wavelength from 200 to $400 \mathrm{~nm}$. The absorbance was recorded at a wavelength of $283 \mathrm{~nm}$. The values of absorbance against the concentration of calibration standard were represented in table 1 . The calibration plot was constructed as concentration vs. absorbance and represented in fig. 3 .

\section{Method validation}

The proposed UV method for the estimation of paliperidone palmitate was validated in terms of parameters like linearity, range, precision, robustness, ruggedness, accuracy and sensitivity. The method was validated as per the guidelines of the International Conference on Harmonization (ICH) [19-21].

\section{Linearity and range}

Linearity of the proposed UV method was established using six different calibration standards viz. 5, 10, 15, 20, 25 and $30 \mu \mathrm{g} / \mathrm{ml}$. Calibration curves in terms of absorbance vs. concentration were plotted. Linear least square regression analysis and $\mathrm{R}$ square value was considered for establishing the linearity of the proposed method. The interval between upper and lower concentration limit with acceptable linearity was reported to be the range of the proposed UV method. Calibration curve was shown in fig. 3. Overlay graph of concentration vs. absorbance was established and depicted in fig. 4.

\section{Accuracy}

The recovery studies were carried out to evaluate the accuracy of the proposed UV method. Three different solutions of PP were prepared in triplicate at a level of $80 \%, 100 \%$ and $120 \%$. Accuracy of the method was determined based on percent recovery from prepared solutions. The results of the accuracy study were shown in table 2 .

\section{Precision}

The precision of the assay method was examined in terms of repeatability by carrying out six independent assays of PP test arrangement and the \% RSD of measurement (intra-day). The intermediate precision of the method was checked by performing same methodology on three consecutive days. The values of \% RSD of intraday and inter-day precision study were shown in table 3 and table 4 respectively. \% RSD of less than 2 was considered to be acceptable.

\section{Robustness}

The robustness of the developed UV method was studied by varying composition co-solvent system. Methanol concentration in the composition of diluent was deliberately changed to 15 and $25 \%$ of bulk. PP in a concentration of $20 \mu \mathrm{g} / \mathrm{ml}$ was prepared utilizing above mentioned co-solvent system independently, $(\mathrm{n}=3)$ and sample were analyzed at $\lambda$ max of $283 \mathrm{~nm}$. The result was determined in terms of $\%$ RSD. \% RSD of less than 2 was considered to be acceptable. The analysis results of the robustness study were represented in table 5.

\section{Ruggedness}

Ruggedness study was carried out by analyzing samples of PP utilizing two different analysts $(n=3)$. The result was depicted in terms of \% RSD. \% RSD of less than 2 was considered to be acceptable. The analysis results of ruggedness study were represented in table 6 .

\section{Sensitivity}

The sensitivity of measurements of PP by the use of the proposed method was estimated in terms of the limit of detection (LOD) and limit of quantitation (LOQ) [20,21]. The sensitivity data of the study were shown in table 7 . The LOD and LOQ were calculated using the following equations.

$$
\begin{aligned}
& \text { LOD }=3.3 \times \frac{\mathrm{N}}{\mathrm{B}} \\
& \mathrm{LOQ}=10 \times \frac{\mathrm{N}}{\mathrm{B}}
\end{aligned}
$$

Where, ' $\mathrm{N}$ ' is the standard deviation of the peak areas of the drugs $(n=3)$, taken as a measure of noise, and 'B' is the slope of the corresponding calibration curve.

\section{Stress degradation studies}

Stress degradation studies with optimized stress conditions were carried out to study the stability-indicating nature of the developed UV spectroscopic method. For each stress condition, three samples were prepared. The stress degradation studies include acid, alkali, hydrolytic, oxidative and photodegradation studies [22-24]. The results of stress degradation studies were represented in table 8 .

\section{Acidic degradation}

$10 \mathrm{mg}$ of PP was added in $20 \mathrm{ml}$ volumetric flask, followed by a methanolic $1 \mathrm{~N}$ hydrochloric acid and volume was made up to $20 \mathrm{ml}$ mark. The solution was stored for $24 \mathrm{~h}$ time.

\section{Alkali degradation}

$10 \mathrm{mg}$ of PP was added in $20 \mathrm{ml}$ volumetric flask, followed by methanolic $1 \mathrm{~N}$ sodium hydroxide and volume was made up to $20 \mathrm{ml}$ mark. The solution was stored for $24 \mathrm{~h}$ time.

\section{Hydrolytic degradation}

$10 \mathrm{mg}$ of PP was added in $20 \mathrm{ml}$ volumetric flask, followed by methanolic Mili-Q-Water and volume was made up to $20 \mathrm{ml}$ mark. The solution was heated at $80^{\circ} \mathrm{C}$ for $6 \mathrm{~h}$ time.

\section{Oxidative degradation}

$10 \mathrm{mg}$ of PP was added in $20 \mathrm{ml}$ volumetric flask, followed by $4 \mathrm{ml}, 10 \%$ hydrogen peroxide solution and methanolic Mili-Q-Water and volume was made up to $20 \mathrm{ml}$ mark. The solution was stored for $24 \mathrm{~h}$ time.

\section{Photodegradation}

The photolytic stability study of the drug was studied in solid-state. The PP was exposed to UV light providing illumination of not less than 200 -watt $\mathrm{h} / \mathrm{m}^{2}$ followed by cool white fluorescence light of not less than 1.2 million Lux-hr. The drug concentration of each exposure was studied by using the proposed UV spectroscopic method [25].

\section{Estimation of drug loading and entrapment efficiency of PP in} long-acting injectable microspheres

Validated method was employed for the estimation of drug loading of PP in injectable depot microspheres formulation. In this study, long acting injectable microspheres formulation of PP was analyzed using pre-validated UV-method and results were reported in terms of average percent assay or percent drug loading. $100 \mathrm{mg}$ of long acting depot injectable microspheres were added in $20 \mathrm{ml}$ methanol and sonicated for $5 \mathrm{~min}$. Volume of the solution was made up to 100 
$\mathrm{ml}$ with Mili-Q-water and mixed by sonication for $2 \mathrm{~min} .5 \mathrm{ml}$ of the solution was withdrawn and added to $50 \mathrm{ml}$ volumetric flask and diluted with Mili-Q-water. The absorbance of the solution was recorded at wavelength $283 \mathrm{~nm}$ and percent drug loading was calculated. The results of drug loading and entrapment efficiency were represented in table 9. Drug loading and entrapment efficiency in long acting injectable microspheres was calculated using following equations [26-28].

$$
\begin{aligned}
& \text { Drug Loading(\%) } \\
& \text { Weight of drug contained in microspheres } \\
& \text { Weight of microspheres }
\end{aligned}
$$$$
\text { Entrapment Efficiency(\%) }=\frac{\text { Practical drug content }}{\text { Therotical drug content }} \times 100
$$

\section{RESULTS AND DISCUSSION}

Preliminary method development trials were executed to find out the solvent system for solublization of PP. Methanol was selected as solvent of choice for initial trials. Firstly, estimation of the wavelength of maximum absorbance was carried out by running absorption spectrum of $30 \mu \mathrm{g} / \mathrm{ml}$ solution of PP in $20 \% \mathrm{v} / \mathrm{v}$ methanol in Mili-Q-water solution. Generally, a solution showing absorbance value less than 1 is considered to be suitable for the determination of wavelength of maximum absorbance $(\lambda \max )$. Full scan was processed using UV software and the $\lambda$ max was identified with the help of software. It was found to be $283 \mathrm{~nm}$ for PP. UV spectrum of PP in 20\% methanolic water was shown fig. 2 .

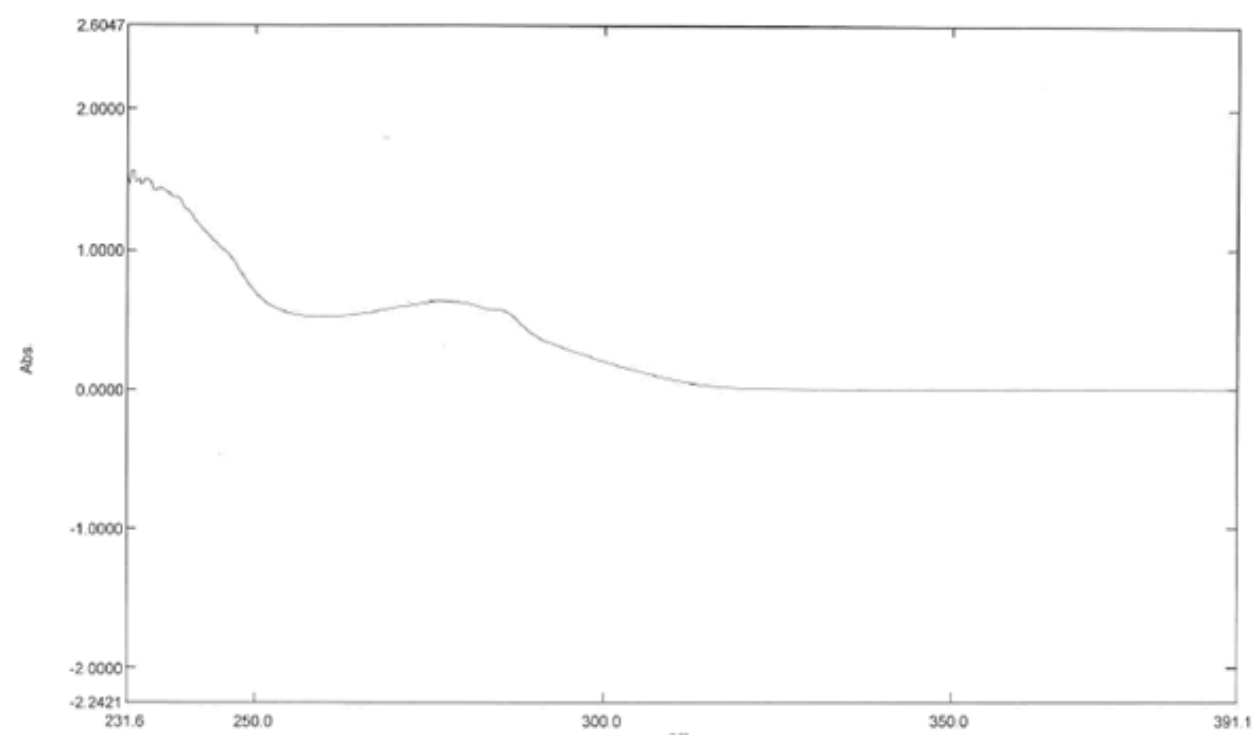

Fig. 2: UV spectrum of paliperidone palmitate in $20 \%$ methanolic water

Different aliquots of PP in the range 0.5 to $3 \mathrm{ml}$ were transferred into a series of $10 \mathrm{ml}$ volumetric flasks, and the volume was made up to the mark with Mili-Q-water to get concentrations 5, 10, 15, 20, 25 and 30 $\mu \mathrm{g} / \mathrm{ml}$, respectively. The solutions were scanned on a spectrophotometer in the UV range 200-400 $\mathrm{nm}$. Overlay UV curves of different calibration standards were shown in fig. 4 . The absorbance of calibration standards was recorded at wavelength $283 \mathrm{~nm}$ and reported as shown in table 1. The calibration plot was constructed as concentration vs. absorbance and represented in fig. 3. Calibration curve shown $\mathrm{R}$ square value of 0.996 as represented in fig. 3 . R square value of more than 0.95 percent is acceptable considering $5 \%$ error. $\mathrm{R}$ square value closer to unity suggests the calibration curve is linear.
Table 1: Concentration vs. absorbance of paliperidone palmitate at $283 \mathrm{~nm}$

\begin{tabular}{ll}
\hline Concentration $(\mu \mathrm{g} / \mathrm{ml})$ & Absorbance* $(\%)$ \\
\hline 5 & $0.1108 \pm 0.02$ \\
10 & $0.2204 \pm 0.06$ \\
15 & $0.3210 \pm 0.01$ \\
20 & $0.3990 \pm 0.04$ \\
25 & $0.5087 \pm 0.08$ \\
30 & $0.6355 \pm 0.11$ \\
\hline
\end{tabular}

*Data represents mean \pm SD $(n=3)$

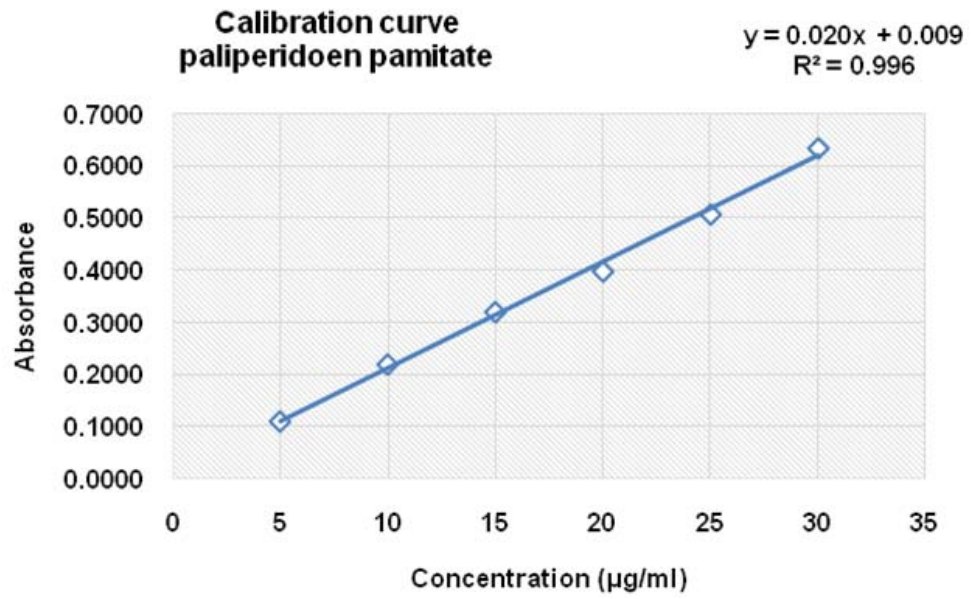

Fig. 3: Calibration curve of paliperidone palmitate 


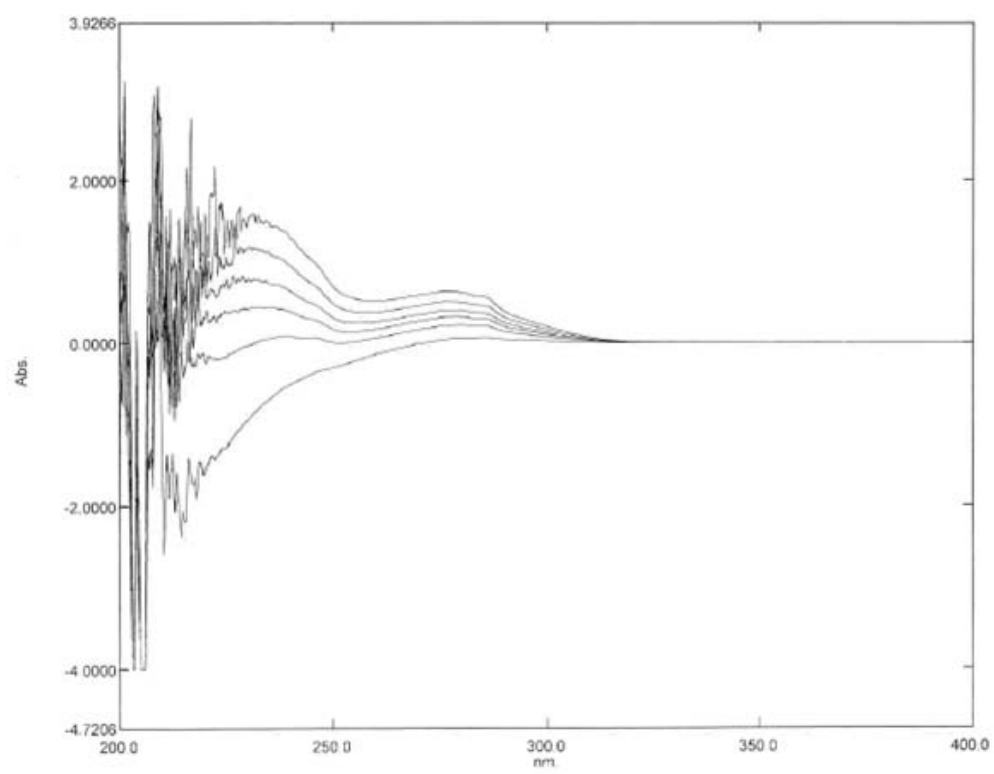

Fig. 4: Overlay UV curves of calibration standards for paliperidone palmitate

A six-point calibration curve of PP with a range from 5 to $30 \mu \mathrm{g} / \mathrm{ml}$ was developed. Concentrations and mean absorbance values are presented in table 1 . The least-square regression analysis equation of calibration curve was $y=0.0204 x+0.0093$ with correlation coefficient 0.996 as shown in fig. 3 . Based on the linearity study, it can be concluded that developed UV method was linear in the prepared concentration range of calibration solutions from 5 to 30 $\mu \mathrm{g} / \mathrm{ml}$. Accuracy is a measure of closeness of the estimated value to the actual amount of the analyte in solution. For PP, accuracy was established using recovery studies. The mean recovery of $80 \%$, $100 \%$ and $120 \%$ standard solution was found to be $99.03,99.21$ and $99.35 \%$ respectively. $\%$ RSD was found to be $0.47 \%, 0.33 \%$ and $0.45 \%$ to $80 \%, 100 \%$ and $120 \%$ standard solution respectively. Results of the accuracy study were represented in table 2 . The results of accuracy showed that \% RSD of analysis was less than 1 ; it reveals that the developed UV method is highly accurate.

Table 2: Accuracy results

\begin{tabular}{|c|c|c|c|c|c|}
\hline Concentration (\%) & Original level $(\mu \mathrm{g} / \mathrm{ml})$ & Amount added $(\mu \mathrm{g} / \mathrm{ml})$ & \% Recovery & Mean \% recovery* & $\% \operatorname{RSD}(n=3)$ \\
\hline 80 & 20 & 16 & 99.54 & 99.03 & 0.47 \\
\hline 80 & 20 & 16 & 98.62 & & \\
\hline 80 & 20 & 16 & 98.94 & & \\
\hline 100 & 20 & 20 & 99.22 & 99.21 & 0.33 \\
\hline 100 & 20 & 20 & 98.87 & & \\
\hline 100 & 20 & 20 & 99.53 & & \\
\hline 120 & 20 & 24 & 99.55 & 99.35 & 0.45 \\
\hline 120 & 20 & 24 & 99.67 & & \\
\hline 120 & 20 & 24 & 99.08 & & \\
\hline
\end{tabular}

*Data represents mean \pm SD $(n=3)$

Precision is the closeness of a measurement to each other. It is expected that the analytical method should be precise. The precision of the method was studied as intraday and interday variations. Intraday precision was determined by analyzing the 10,15 and 20 $\mu \mathrm{g} / \mathrm{ml}$ of PP solutions for three times in the same day and results are represented in table 3 . Interday precision was determined by analyzing the 10,15 , and $20 \mu \mathrm{g} / \mathrm{ml}$ solutions of PP for three consecutive days and results represented in table 4. Overall, \% RSD values of less than 2 in the case of both intra-day and inter-day precision showed that the developed UV method is precise.

\begin{abstract}
Robustness of the analytical method was the study of the impact of small deliberate changes in method parameters on method performance. It was desired that such small changes should not impact the performance of the analytical method. In this study, the robustness of the proposed UV method was established by modifying the composition of the co-solvent system in the range of 15 to $25 \%$ of methanol in the Mili-Q-Water. The results of the robustness study were shown in table $5 . \%$ RSD values for the concentration of $20 \mu \mathrm{g} / \mathrm{ml}$ concentration with a small change in the composition of the solvent system were found to be less than $2 \%$ RSD. It showed that the proposed UV method is robust in nature.
\end{abstract}

Table 3: Intraday precision results

\begin{tabular}{|c|c|c|c|c|c|c|c|c|c|}
\hline \multirow{2}{*}{$\begin{array}{l}\text { Conc. } \\
(\mu \mathrm{g} / \mathrm{ml})\end{array}$} & \multicolumn{3}{|l|}{ Morning } & \multicolumn{3}{|l|}{ Afternoon } & \multicolumn{3}{|l|}{ Evening } \\
\hline & $\begin{array}{l}\text { Mean } \\
\text { absorbance* }\end{array}$ & $\begin{array}{l}\% \\
\text { Assay }\end{array}$ & $\begin{array}{l}\% \text { RSD } \\
(n=3)\end{array}$ & $\begin{array}{l}\text { Mean } \\
\text { absorbance* }\end{array}$ & $\begin{array}{l}\text { \% } \\
\text { Assay }\end{array}$ & $\begin{array}{l}\% \text { RSD } \\
(n=3)\end{array}$ & $\begin{array}{l}\text { Mean } \\
\text { absorbance* }\end{array}$ & $\begin{array}{l}\text { \% } \\
\text { Assay }\end{array}$ & $\begin{array}{l}\% \text { RSD } \\
(n=3)\end{array}$ \\
\hline 10 & $0.2107 \pm 0.01$ & 98.73 & 0.62 & $0.2109 \pm 0.06$ & 98.82 & 1.24 & $0.2115 \pm 0.04$ & 99.12 & 0.95 \\
\hline 15 & $0.3129 \pm 0.04$ & 99.22 & 1.09 & $0.3133 \pm 0.02$ & 99.35 & 0.98 & $0.3123 \pm 0.07$ & 99.02 & 1.14 \\
\hline 20 & $0.4104 \pm 0.07$ & 98.31 & 1.43 & $0.4102 \pm 0.08$ & 98.26 & 0.54 & $0.4118 \pm 0.08$ & 98.65 & 1.62 \\
\hline
\end{tabular}

*Data represents mean $\pm \mathrm{SD}(\mathrm{n}=3)$ 
Table 4: Interday precision results

\begin{tabular}{|c|c|c|c|c|c|c|c|c|c|}
\hline \multirow{2}{*}{$\begin{array}{l}\text { Conc. } \\
(\mu \mathrm{g} / \mathrm{ml})\end{array}$} & \multicolumn{3}{|l|}{ Day 1} & \multicolumn{3}{|l|}{ Day 2} & \multicolumn{3}{|l|}{ Day 3} \\
\hline & $\begin{array}{l}\text { Mean } \\
\text { absorbance* }\end{array}$ & $\begin{array}{l}\% \\
\text { Assay }\end{array}$ & $\begin{array}{l}\text { \%RSD } \\
(n=3)\end{array}$ & $\begin{array}{l}\text { Mean } \\
\text { absorbance* }\end{array}$ & $\begin{array}{l}\% \\
\text { Assay }\end{array}$ & $\begin{array}{l}\text { \%RSD } \\
(n=3)\end{array}$ & $\begin{array}{l}\text { Mean } \\
\text { absorbance* }\end{array}$ & $\begin{array}{l}\% \\
\text { Assay }\end{array}$ & $\begin{array}{l}\text { \%RSD } \\
(n=3)\end{array}$ \\
\hline 10 & $0.2104 \pm 0.09$ & 98.58 & 0.85 & $0.2105 \pm 0.04$ & 98.63 & 1.04 & $0.2108 \pm 0.09$ & 98.77 & 1.07 \\
\hline 15 & $0.3127 \pm 0.05$ & 99.15 & 1.24 & $0.3137 \pm 0.08$ & 99.48 & 0.67 & $0.3127 \pm 0.05$ & 99.15 & 1.24 \\
\hline 20 & $0.4110 \pm 0.06$ & 98.46 & 1.07 & $0.4105 \pm 0.11$ & 98.33 & 0.88 & $0.4119 \pm 0.06$ & 98.68 & 0.79 \\
\hline
\end{tabular}

*Data represents mean $\pm \mathrm{SD}(\mathrm{n}=3)$

Table 5: Robustness results

\begin{tabular}{llll}
\hline Concentration $(\boldsymbol{\mu g} / \mathbf{m l})$ & \% Methanol & Absorbance & 0.4104 \\
& \% RSD (n=3) & 0.4124 \\
& 15 & & 0.4154 \\
& & 0.61 \\
& 20 & 0.4114 & 0.59 \\
& & 0.4107 & 0.4112 \\
& & 0.4125 \\
\end{tabular}

Data represents mean $\pm \mathrm{SD}(\mathrm{n}=3)$

The ruggedness of the proposed method was determined for 20 $\mu \mathrm{g} / \mathrm{ml}$ concentration of PP by analysis of aliquots from a homogenous slot by two analysts using the same operational and environmental conditions. The results of the ruggedness study were shown in table $6 . \%$ RSD of UV absorbance testing under defined method conditions for analyst 1 and analyst 2 was found to be 1.33 and $1.27 \%$. The data of robustness (table 6) of UV method showed the proposed method is robust.

Table 6: Ruggedness results

\begin{tabular}{llll}
\hline Concentration $(\boldsymbol{\mu g} / \mathbf{m l})$ & Analyst 1 & Analyst 2 \\
\cline { 2 - 4 } & Absorbance & \% RSD (n=3) & Absorbance \\
\hline 20 & 0.3995 & 1.33 & 0.3993 \\
& 0.3997 & & 0.3989 \\
& 0.3994 & 0.3994 & 0.27 \\
\hline
\end{tabular}

Data represent mean $\pm S D(n=3)$

Sensitivity of UV spectroscopic method can be estimated by calculating LOD and LOQ. LOQ is the lowermost concentration that can be estimated with acceptable accuracy and precision. LOD and
LOQ of the proposed UV method were found to be 0.03 and 0.10 $\mu \mathrm{g} / \mathrm{ml}$, respectively as shown in table 7 . The results of LOD and LOQ showed that the developed method is sensitive.

Table 7: UV method sensitivity data

\begin{tabular}{lll}
\hline Concentration $(\boldsymbol{\mu g} / \mathbf{m l})$ & Absorbance $(\%)$ & Sample 2 \\
\cline { 2 - 3 } & Sample 1 & 0.2207 \\
\hline Standard Deviation $(\mathrm{n}=3)$ & 0.2206 & \\
LOD & 0.0002082 & \\
LOQ & $0.03 \mu \mathrm{g} / \mathrm{ml}$ & \\
\hline
\end{tabular}

Stress degradation studies revealed that PP prone to degradation on acidic, alkaline and oxidative stress. PP was found stable under hydrolytic and photodegradation challenges. The developed method was not capable to quantify degradation products, but able to estimate percent degradation calculated from assay term. The developed method was found suitable to study the stress degradation of PP. Stress degradation parameters, stress conditions, conc. (\% assay) and \% degradation was represented in table 8.

Table 8: Stress degradation studies

\begin{tabular}{lllll}
\hline S. No. & Parameter & Stress condition & Conc. (\% assay) \\
\hline 1 & Control & --- & 99.88 & \% Degradation \\
2 & Acid & $1 \mathrm{~N}-\mathrm{HCl}, 24 \mathrm{H}$ & 83.60 & 0.12 \\
3 & Alkali & $1 \mathrm{~N}-\mathrm{NaOH}, 24 \mathrm{H}$ & 81.60 & 18.4 \\
4 & Hydrolytic/Thermal & $80^{\circ} \mathrm{C}, 6 \mathrm{H}$ & 99.86 & 0.14 \\
5 & Oxidative & $10 \% \mathrm{H} 2 \mathrm{O} 2,24 \mathrm{H}$ & 91.58 & 0.14 \\
6 & Fluroscent & $1.2 \mathrm{Million} \mathrm{Lux.} \mathrm{Hrs}$ & 99.86 & 0.19 \\
7 & UV & $200 \mathrm{Watt}$ Hrs $/$ Square Meter & 99.81 & \\
\hline
\end{tabular}


The results of the stress degradation study of PP were in accordance with the forced degradation study carried out by Sawant $S D$ and Barge $V U$, which reported that PP undergone degradation in acidic and basic stress conditions; while PP was stable under hydrolytic, photo and oxidative conditions [29]. As well, Mathad VT et al. reported stress degradation profile of paliperidone showed degradation under acidic, basic and oxidative stress [30].

The developed UV spectroscopic method was successfully applied for the estimation of drug loading in long-acting injectable microspheres dosage form. Average practical drug loading $(n=3)$ of PP in long-acting injectable microspheres dosage form was found to be $32.77 \pm 0.58 \%$. The developed method was studied to estimate drug loading and entrapment efficiency in microspheres during stability study of developed microspheres. The analysis data of drug loading after exposure to different stability conditions were tabulated in table 9 .

Entrapment efficiency of microspheres was found to be $98.32 \%$. Drug loading and entrapment efficiency were studied on stability conditions like $40{ }^{\circ} \mathrm{C} / 75 \% \mathrm{RH}$ and $25^{\circ} \mathrm{C} / 60 \% \mathrm{RH}$ for $3 \mathrm{mo}$ as per ICH guidelines of stability testing [31]. Results of drug loading were found to be in the range from 32.70 to $32.77 \%$. The results of entrapment efficiency were found to be between 98.12 and $98.32 \%$. The data in table 9 showed that the developed method was capable to estimate drug loading and entrapment efficiency of prepared microspheres during initial analysis and stability analysis.

Table 9: Drug loading analysis of long acting injectable microspheres of PP

\begin{tabular}{lll}
\hline Stability condition/Interval & Drug loading \pm SD* (\%) & Entrapment efficiency \pm SD* \\
\hline Initial & $32.77 \pm 0.58$ & $98.32 \pm 0.84$ \\
$40{ }^{\circ} \mathrm{C} / 75 \% \mathrm{RH}-1$ Mo & $32.73 \pm 0.32$ & $98.19 \pm 0.57$ \\
$40^{\circ} \mathrm{C} / 75 \% \mathrm{RH}-3$ Mo & $32.70 \pm 0.69$ & $98.12 \pm 1.09$ \\
$25^{\circ} \mathrm{C} / 60 \% \mathrm{RH}-1$ Mo & $32.75 \pm 0.43$ & $98.26 \pm 0.68$ \\
$25^{\circ} \mathrm{C} / 60 \% \mathrm{RH}-3$ Mo & $32.73 \pm 0.55$ & $98.19 \pm 0.80$ \\
\hline
\end{tabular}

*SD: Standard Deviation, $\mathrm{n}=3$

\section{CONCLUSION}

A simple, accurate and precise UV-Visible spectrophotometric method for the estimation of PP was developed and validated. The Proposed method was found to be robust and rugged in nature and was successfully used for the estimation of drug loading of PP in injectable depot microspheres.

\section{FUNDING}

Nil

\section{AUTHORS CONTRIBUTIONS}

All the authors contributed equally.

\section{CONFLICT OF INTERESTS}

Declared none

\section{REFERENCES}

1. Dixon LB, Lehman AF, Levine J. Conventional antipsychotic medications for schizophrenia. Schizophr 1995;21:567.

2. Chue $\mathrm{P}$, Chue J. A critical appraisal of paliperidone long-acting injection in the treatment of the schizoaffective disorder. Ther Clin Risk Manag 2016;27:109-16.

3. Samtani MN, Vermeulen A, Stuyckens K. Population pharmacokinetics of intramuscular paliperidone palmitate in patients with schizophrenia: a novel once-monthly, long-acting formulation of an atypical antipsychotic. Clin Pharmacokinet 2009;48:585-600.

4. Bishara D. Once monthly paliperidone injection for the treatment of schizophrenia. Neuropsych Dis Treatment 2010;6:561-72.

5. Fang Y, Zhang N, Li Q, Chen J, Xiong S, Pan W. Characterizing the release mechanism of donepezil loaded PLGA microspheres in vitro and in vivo. J Drug Delivery Sci Technol 2019;51:430-7.

6. Andharia JV, Shen J, Choi S, Wang Y, Zou Y, Burgess DJ. Development of in vitro-in vivo correlation of parenteral naltrexone loaded polymeric microspheres. J Controlled Release 2017;255:27-35.

7. Zhang C, Wu l, Tao A, Bera H, Tang X, Cun D, et al. Formulation and in vitro characterization of long-acting PLGA injectable microspheres encapsulating a peptide analog of LHRH. J Mater Sci Technol 2021;63:133-44.

8. Thakur B, Kumar I. New developed and validated spectroscopic method for the simultaneous estimation of terbinafine hydrochloride and fluconazole. Int J Pharm Pharm Sci 2020;12:19-25.

9. Pokala RV, Kumari K, Bollokola HB. UV spectroscopy method development and validation of Sulfadiazine and Trimethoprim in combined dosage form. Int J Pharm Pharm Sci 2018;10:103-7.
10. Atole DM, Rajput HH. Ultraviolet spectroscopy and its pharmaceutical applications-a brief review. Asian J Pharm Clin Res 2018;11:59-66.

11. Yadav N, Goyal A. A validated spectrophotometric method for determination of Vilazodone hydrochloride in pharmaceutical dosage form. Int J Curr Pharm Res 2017;9:132-5.

12. Satya T, Yadav GKS, Chakarvarth IE. New simple UVspectrophotometric determination of paliperidone palmitate in tablets. Int J Eng Sci Res Tech 2014;3:411-3.

13. Patil SV, Shirkhedkar AA. Application of uv-spectrophotometry and rp-hptlc methods for estimation of paliperidone in bulk and tablets. J Globe Trends Pharm Sci 2015;6:2770-6.

14. Trivedi RK, Jupudi R, Patel MC, Trivedi DR, Jogia HA. A validated Spectrophotometric method for determination of paliperidone palmitate in bulk drug and its pharmaceutical dosage form. J Pharm Pharm Sci 2013;2:37-41.

15. Jane M, Joshi C, Jonils A. Analytical methods for estimation of paliperidone. Int J Res Pharm 2011;2:158-61.

16. Rudragangaiah $S$, Bhatta RG, Kottapa SB. Stability indicating RP-HPLC method for the quantification of paliperidone in bulk and solid dosage form to establish validation and stabilityindicating parameters. Indian J Pharma Educ Res 2019;53(4s):691-8.

17. Sherje AP, Londhe V. Stability indicating HPLC method for determination of paliperidone in bulk. Int J Pharmatech Res 2015;8:157-63.

18. Trivedi RK, Jain P, Patel MC, Chatrabhuji PM, Trived DR. A rapid, stability-indicating RP-UPLC method for determination of paliperidone palmitate in a depot injectable formulation. J Appl Pharm Sci 2013;3:87-92.

19. ICH. Validation of Analytical Procedure, Text and Methodology Q2(R1), International Conference on Harmonization, IFPMA, Geneva, Switzerland; 2005.

20. Martins YA, Oliveira CL. Development and validation of an UV spectroscopic method for determination of thiamphenicol in dosage form. J Appl Spectrosc 2019;86:629-35.

21. Prasad AR, Thireesha B. UV spectrophotometric method development and validation for determination of lornoxicam in microsponges. Int J Appl Pharm 2018;10:74-8.

22. Blessy M, Patel RD, Prajapati PN, Agrawal YK. Development of forced degradation and stability indicating studies of drugs-a review. J Pharma Anal 2014;4:159-65.

23. Doredla NR, Yengisetty B. Method development and validation of forced degradation studies of pioglitazone hydrochloride by using UV spectroscopy. Int J Pharmatech Res 2012;4:1750-7.

24. Devi V, Sekar V. Stress degradation studies of hydrochlorothiazide and development of a validated method by UV spectroscopy. Int J Sci Res 2018;7:403-6. 
25. ICH. Photostability testing of new active substances and products Q1B(R4), International Conference on Harmonization IFPMA, Geneva, Switzerland; 1996.

26. Dey S, Pramanik S, Malgope A. Formulation and optimization of sustained-release stavudine microspheres using response surface methodology. Int Sch Res Notices; 2011. p. 627-33.

27. Chen W, Palazzo A, Henrick WE, Kok RJ. Effect of particle size on drug loading and release kinetics of gefitinib-loaded PLGA microspheres. Mol Pharm 2017;14:459-67.

28. Reddy KA, Karpagam S. Preparation and characterization of drug-loaded phthalic anhydride based hyperbranched polyesteramides microspheres. Pharm Chem J 2017;50:857-64.
29. Sawant SD, Barge VU. Identification and characterization of forced degradation products of paliperidone palmitate using LC-APCI-Ion trap-MS. J Pharm Res 2013;6:39-47.

30. Mathad VT, Jadhav SA, Landge SB, Choudhari PM, Solanki PV, Bembalkar SR. Stress degradation behavior of paliperidone, an antipsychotic drug and development of suitable stabilityindicating RP-LC method. Chromatogr Res Int 2011:1-10. https://doi.org/10.4061/2011/256812

31. ICH. Stability testing of new drug substances and products Q1A(R2), International Conference on Harmonization, IFPMA, Geneva, Switzerland; 2003. 